\title{
Islet Neogenesis Associated Protein Antibody Measurement
}

National Cancer Institute

\section{Source}

National Cancer Institute. Islet Neogenesis Associated Protein Antibody Measurement. NCI Thesaurus. Code C81987.

The determination of the amount of islet neogenesis associated protein antibody present in a sample. 